\title{
Evaluation of Physical and Chemical Properties of OPC and PPC Cement
}

\author{
Shrikant Jahagirdar, Vinayak Patki, Shrinivas Metan
}

\begin{abstract}
Cement is a one of the largest industrial product that is manufactured in more than 120 countries. Increasing costs of cement have recorded a continuous growth in its usage in the Indian construction industry. India is marching forwarding cement Production. Cement was first invented by the Egyptians. India started the same in 1904 in Tamil Nadu in Ariyalur. OPC and PPC are the two most widely used cement types in India. There are significant differences in mortar strength, fineness, consistency, soundness, chemical composition and setting time of same type of cement collected from different cement suppliers. Experiments were conducted on 9 brands of OPC and 6 brands of PPC samples collected from local market in Solapur, Maharashtra, India. In this study, the amounts of main chemical constituents such as Silicon oxide (SiO2), Aluminum oxide (Al2O3), Iron Oxide (Fe2O3), Magnesium Oxide (MgO), Sulphur Trioxide (SO3), Calcium Oxide (CaO), and Loss on Ignition (LOI) were determined and compared. All the results pbtained during this study were presented in order to provide qualitative and quantitative differentiation between cement sample. These results were compared with limits specified in the BIS. The possible reasons for variation in chemical composition and their effect on properties of cement have been discussed.
\end{abstract}

\section{Index Terms-Cement, OPC, PPC, XRF.}

\section{INTRODUCTION}

Precise and scientific process yields Cement as a fine mineral powder. When mixed with water, this powder transforms into a hardened paste that binds all ingredients and gains strength when cured in water Cement is the main ingredient of concrete. It has wide applications in different civil engineering sectors with capability to produce excellent quality construction.

Strength of cement is the most important property amongst all physical properties of cement. Grades mentioned on the cement bags indicates compressive strength of the cement cubes prepared out of that cement in a standard BIS procedures. Commonly available grades are 43 and 53 grade.

As per the studies on Effect of Fineness on the Cement [1] in general conditions, cements with a higher fineness value will have tendancy to hydrate rapidly and gains higher early age strength, due to this fact, use of finer cements is adopted in the mix. design of high early strength concrete. On the other hand chemical composition of cement has effect on the functioning of cement and finer the cement more is the

Revised Version Manuscript Received on 16 September, 2019.

ShrikantJahagirdar, Professor in Civil engineering, N K Orchid

College of Engineering and technology, Solapur, Karnataka, India.

(Email: shrikantjahagirdar@orchidengg.ac.in)

VinayakPatki, Professor in Civil engineering, N K Orchid College of Engineering and technology, Solapur, Karnataka, India

(Email: vinayakpatki@ orchidengg.ac.in)

ShrinivasMetan, Professor in Mechanical Engineering, N K Orchid

College of Engineering and technology, Solapur,Karnataka, India

(Email: shrinivasmetan@ orchidengg.ac.in) surface area that results in more compressive strength [2]. It is also important to note that Portland cement characteristics are relatively unchanged over the last 10 years [3].

A study also revealed that at increased ages, strength is affected more by the presence of coarser particles as compared to finer ones [4]. Similar comparative study on cements in Nigeria found that, the density value of concrete cubes did not show variation but in turn dependent on the age of curing while the strength increases with the age of curing [5]. Type of storage method may also affect strength. Significant reduction in strength due to ageing is also reported. If cement is stored in air tight condition, it gives the expected strength up to 3 months [6]. XRF technique can be used to detect chemical composition of cement $\left(\mathrm{Cl}, \mathrm{SO}_{3}\right.$, $\mathrm{MgO}, \mathrm{C}_{3} \mathrm{~S}, \mathrm{C}_{2} \mathrm{~S}, \mathrm{C}_{3} \mathrm{~A}, \mathrm{C}_{4} \mathrm{AF}$ ) [7].

\section{MATERIAL AND METHODS}

Nine OPC and six PPC cement brands cement were collected from local market in Solapur, Maharashtra, India as given in Table 1 and Table 2. In order to analyse chemical composition of cement samples The modern technology of XRF was used. The XRF testing was carried out at IIT Pawai, Bombay.

Table 1 OPC Brands

\begin{tabular}{|c|c|c|}
\hline $\begin{array}{c}\text { Sr. } \\
\text { no. }\end{array}$ & Names of brand & Brand code \\
\hline 1 & Coromandal king & OPC-1 \\
\hline 2 & CCI & OPC-2 \\
\hline 3 & Sagar & OPC-3 \\
\hline 4 & Bhavya & OPC-4 \\
\hline 5 & Chettinad & OPC-5 \\
\hline 6 & Penna & OPC-6 \\
\hline 7 & Deccan & OPC-7 \\
\hline 8 & Zuari & OPC-8 \\
\hline 9 & Ultratech & OPC-9 \\
\hline
\end{tabular}

Table 2 PPC Brands

\begin{tabular}{|r|c|c|}
\hline $\begin{array}{c}\text { Sr. } \\
\text { no. }\end{array}$ & Names of brand & Brand code \\
\hline 1 & Birla Gold & PPC-1 \\
\hline 2 & Ambuja & PPC-2 \\
\hline 3 & ACC & PPC-3 \\
\hline 4 & Sagar & PPC-4 \\
\hline 5 & Ultratech & PPC-5 \\
\hline 6 & Bhrati & PPC-6 \\
\hline
\end{tabular}


Table 3 shows tests conducted on OPC and PPC brands of cement as per BIS.

Table 3: List of tests as per BIS [9,10]

\begin{tabular}{|c|c|c|c|}
\hline $\begin{array}{l}\text { Sr. } \\
\text { no. }\end{array}$ & Tests & $\begin{array}{c}\text { BIS } \\
\text { Code }\end{array}$ & Standards \\
\hline 1 & Fineness & $\begin{array}{l}\text { BIS : } \\
\text { 4031, } \\
\text { Part-I, } \\
\text { (1988) }\end{array}$ & $\leq 10 \%$ \\
\hline 2 & $\begin{array}{c}\text { Standard } \\
\text { Consistency }\end{array}$ & $\begin{array}{c}\text { BIS : } \\
\text { 4031, } \\
\text { Part-IV, } \\
\text { (1988) }\end{array}$ & - \\
\hline 3 & Soundness & $\begin{array}{c}\text { BIS : } \\
\text { 4031, } \\
\text { Part-III, } \\
\text { (1988) }\end{array}$ & $<10 \mathrm{~mm}$ \\
\hline 4 & $\begin{array}{l}\text { Initial Setting } \\
\text { Time Final } \\
\text { Setting Time }\end{array}$ & $\begin{array}{c}\text { BIS : } \\
\text { 4031, } \\
\text { Part-V, } \\
\text { (1988) }\end{array}$ & $\begin{array}{l}>30 \text { minutes } \\
<600 \text { minutes }\end{array}$ \\
\hline 5 & $\begin{array}{l}\text { Compressive } \\
\text { Strength } \\
\text { For OPC } 53 \\
\text { For PPC }\end{array}$ & $\begin{array}{c}\text { BIS : } \\
\text { 4031, } \\
\text { Part- VI, } \\
\text { (1988) }\end{array}$ & $\begin{array}{c}\text { After } 28 \\
\text { days-53 MPa } \\
\text { After } 28 \\
\text { days-33 Mpa }\end{array}$ \\
\hline 6 & Loss on Ignition & $\begin{array}{l}\text { BIS : } \\
4032, \\
(1985)\end{array}$ & $<5 \%$ \\
\hline
\end{tabular}

\section{RESULTS AND DISCUSSIONS}

\section{A. XRF Analysis of OPC cement}

Chemical composition and compound composition of OPC and PPC cement are determined using X-ray Flourescence (XRF) analyzer.

Figure 1 shows the $\mathrm{Al}_{2} \mathrm{O}_{3}$ content present in the tested cement samples for OPC-53 grade. Alumina is Aluminum oxide, Alumina responsible for imparting quick setting property to the cement, Clinkering temperature is reduced by the presence of required quantity of alumina, Excess alumina results in weakening of the cement. As per BIS approximate limit of Alumina is 3-8\%.

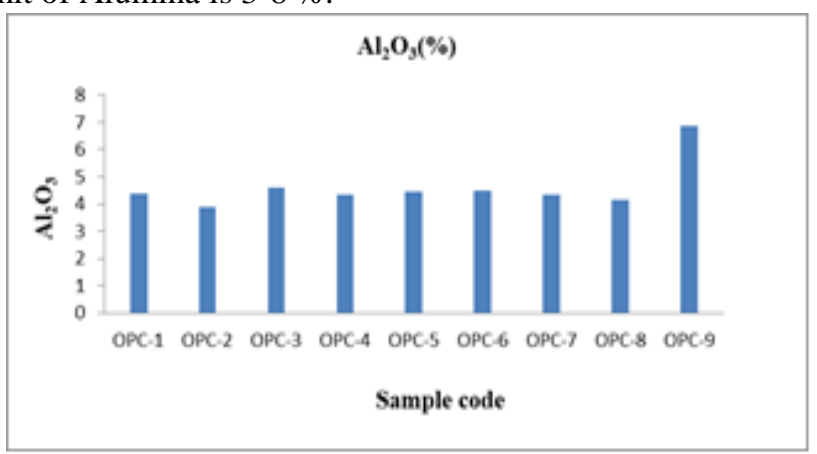

Figure 1: $\mathrm{Al}_{2} \mathrm{O}_{3}$ Variation in $\mathrm{OPC}$ cements

All samples are showing the $\mathrm{Al}_{2} \mathrm{O}_{3}$ content as per the requirements. Hence it will help in imparting quick setting property to the cement.

Figure 2 shows the $\mathrm{CaO}$ (Lime) content found in all 9 samples of OPC. Presence of appropriate lime quantity results in formation of silicates and aluminates of calcium. Insufficient quantity of lime reduces the strength of cement and causes cement to set quickly. Excess lime makes cement unsound and cause cement to expand and disintegrate. As per requirement limit of lime in Portland cement is 60-67\%.

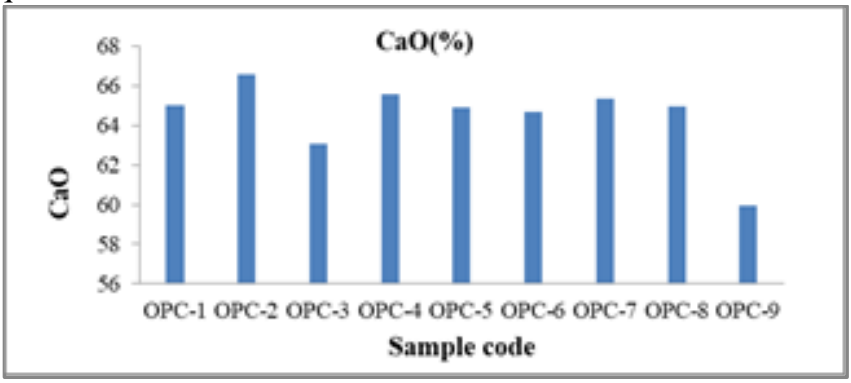

Figure 2: CaO Variation in OPC cements

$\mathrm{CaO}$ is major compound in gaining the strength of cement. The results were showing the lime content as per BIS requirements which are expected to give the good strength.

Figure 3 shows $\mathrm{Fe}_{2} \mathrm{O}_{3}$ content in the different cement samples tested in XRF analyzer. Iron oxide is contributing for imparting color to cement and it acts as a flux. At a very high temperature it takes part into chemical reaction with calcium and aluminum to form tricalciumaluminoferrite, tricalciumaluminoferrite which results in hardness and gives strength to cement. As per requirement amount of $\mathrm{Fe}_{2} \mathrm{O}_{3}$ in cement is approximately is equal to 0.5-6\%. All the samples are showing the $\mathrm{Fe}_{2} \mathrm{O}_{3}$ content as per requirements, hence it helps to gaining the hardness, strength and colour to the cement $[11,12]$.

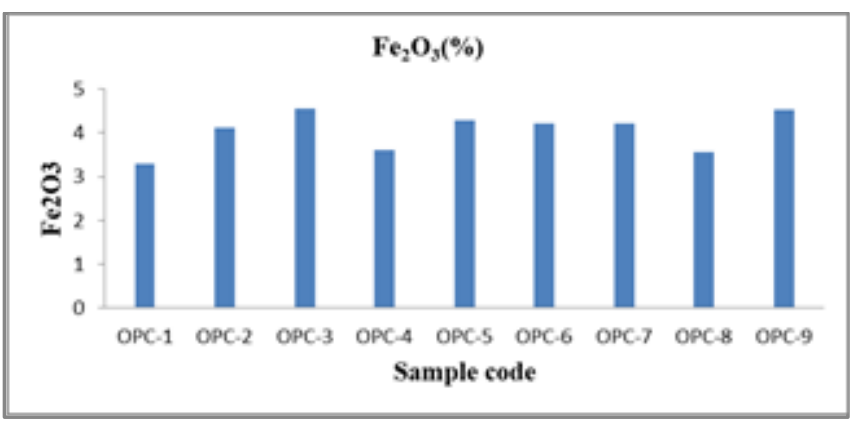

Figure 3: Variation in Fe2O3 content in OPC cement

Figure 4 shows $\mathrm{SiO}_{2}$ content in the OPC samples tested using XRF analyzer. Silicon dioxide is known as silica. Sufficient quantity of silica should be present in cement to dicalcium and tricalcium silicate. Strength of cement can be attributed to presence of silica. Acceptable range of silica in cement is about $30 \%$. As per requirement approximate limit of Silicon dioxide is $17-25 \%$.

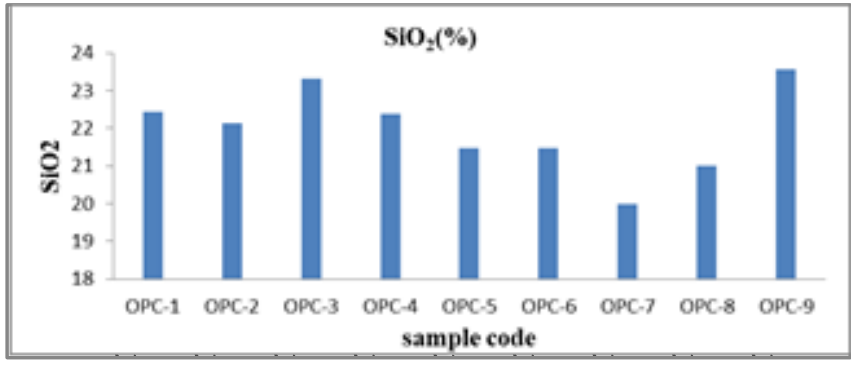

Figure 4: Variation in $\mathrm{SiO}_{2}$ content in OPC cement

Published By:

Blue Eyes Intelligence Engineering

\& Sciences Publication 
It is second major compound which imparts strength to the cement.

\section{B. XRF Analysis of OPPC cement}

Figure 5 shows $\mathrm{Al}_{2} \mathrm{O}_{3}$ content present in all 6 cement samples tested using XRF analyzer.

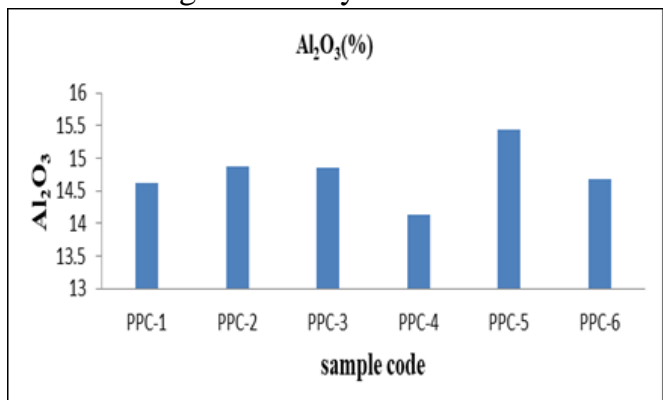

Figure 5: Variation in $\mathrm{Al}_{2} \mathrm{O}_{3}$ Content in PPC Cement

The amount of $\mathrm{Al}_{2} \mathrm{O}_{3}$ content in the $\mathrm{PPC}$ is quite high as compared to OPC. This increases initial and final setting time of cement.

Figure 6 shows the amount of $\mathrm{CaO}$ present in the 6 cement samples of PPC.

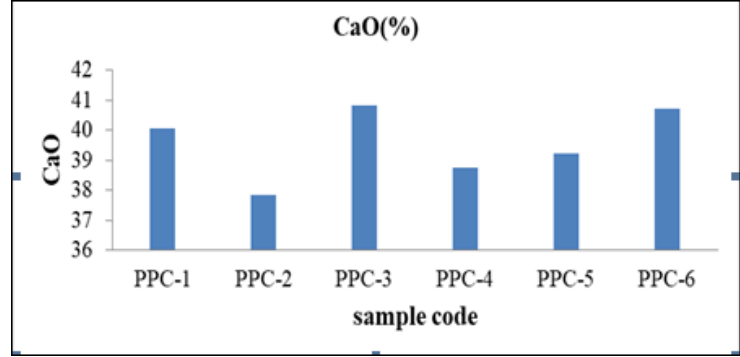

Figure 6: Variation in $\mathrm{CaO}($ Lime) Content in PPC cement

The amount of lime in PPC is reduced due to the addition of fly ash during the manufacturing process. As the lime content is less it will gives less compressive strength as compared to the OPC.

Figure 7 shows $\mathrm{Fe}_{2} \mathrm{O}_{3}$ content present in all tested samples using XRF Analyzer.

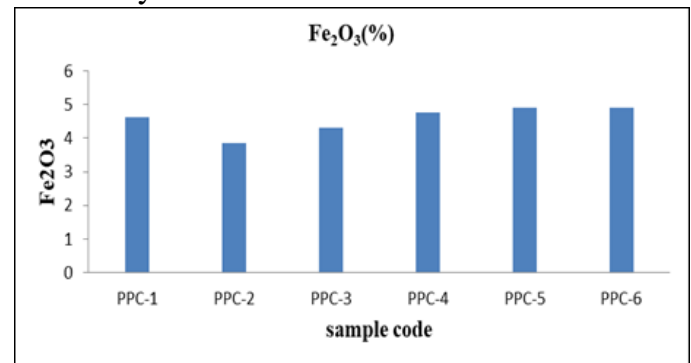

Figure 7: Variation in $\mathrm{Fe}_{2} \mathrm{O}_{3}$ Content in PPC cemnt

All samples are showing the $\mathrm{Fe}_{2} \mathrm{O}_{3}$ content within the limits. Hence it helps to gain the hardness, strength and colour.

Figure 8 shows the $\mathrm{SiO}_{2}$ content in the samples tested using XRF Analyzer.

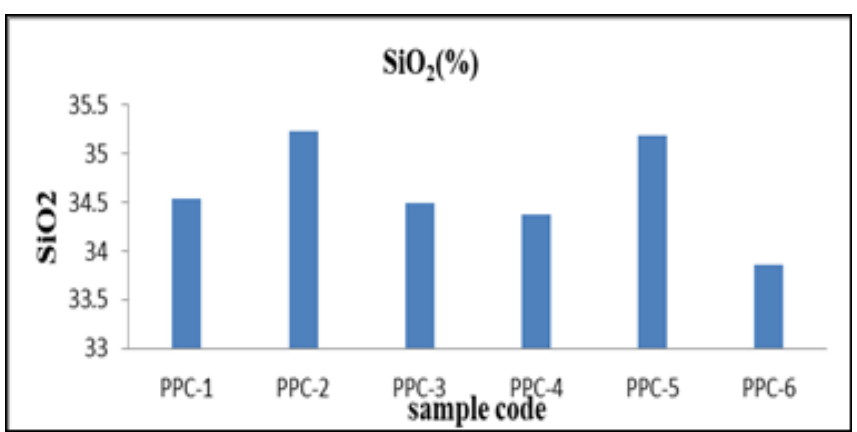

Figure 8: Variation in $\mathrm{SiO}_{2}$ Content in PPC cement

Results of $\mathrm{SiO}_{2}$ content of all the samples are meeting the requirements. It will help for gaining the strength to the cement.

\section{PHYSICAL TESTS FOR OPC CEMENT}

Figure 9 shows results for fineness of cement. Fineness varies from $3 \%$ to $20 \%$. According to BIS requirement, fineness should be less than or equal to $10 \%$. All cement samples are within limits except sample code OPC-1 and 8.

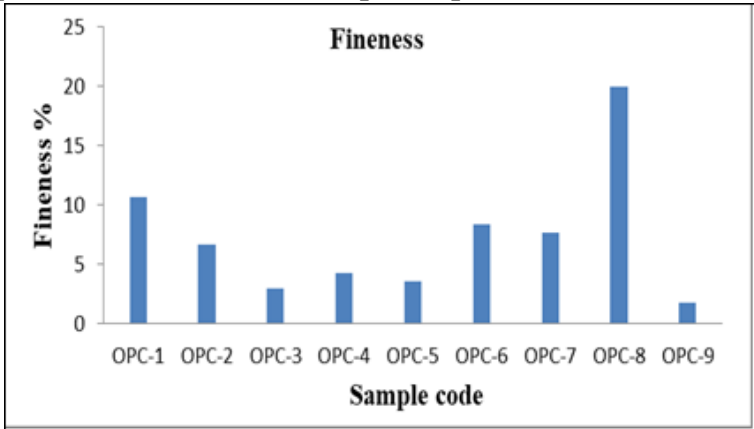

Figure 9: fineness Variation in OPC cement

As the sample code OPC- 1 and 8 are not meeting the BIS requirements, these cements should not be used for making the concrete where high strength is required but could be used for nonstructural elements.

Standard consistency of cement paste was determined using the Vicat's Apparatus according to BIS for all 9 samples. Results of consistency are graphically represented in Figure 10.

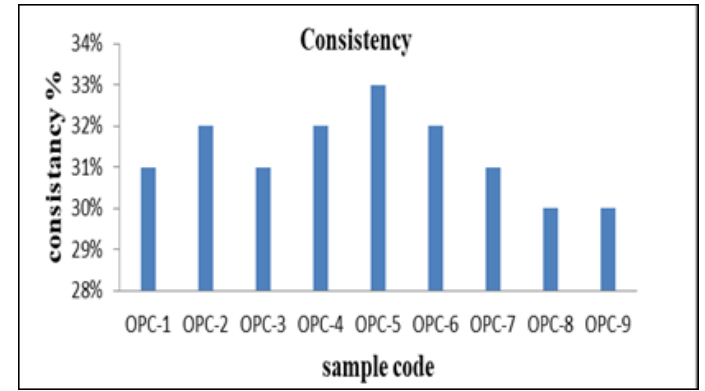

Figure 10 Results of Consistency Test

This test helps to determine water content for other tests like initial and final setting time, soundness and compressive strength. Generally the normal consistancy ranges from 26 to $33 \%$. 
Soundness test (Expansion) was done according to standard BIS procedures, using Le-Chateliermould. Results are shown in Figure 11. All samples are meeting requirements of the BIS specifications. The limiting value of soundness for OPC is $10 \mathrm{~mm}$.

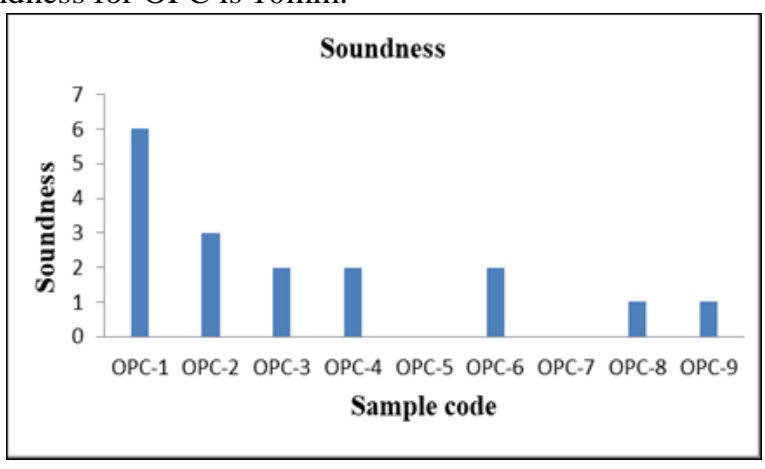

Figure 11 Results of Soundness Test

By Le-chatelier method presence of unburnt lime $(\mathrm{CaO})$ could be determined, which is accountable for volume expansion in cement mortar or in cement concrete. Presence of unburnt lime may develop cracks in the cement because of increase in volume. As all the cement samples were within BIS limits these are not going to affect too much.

Initial setting time is important for transportation, placing and compaction of cement concrete. Determination of final setting time period helps to decide time of safe removal of scaffolding or formwork. According to BIS specifications initial and final setting time should be not less than 30 minutes and should not be more than 600 minutes respectively. Initial setting time of most samples lies between 60 to 100 minutes and final setting lies between 500 to 550 minutes (figure 12).

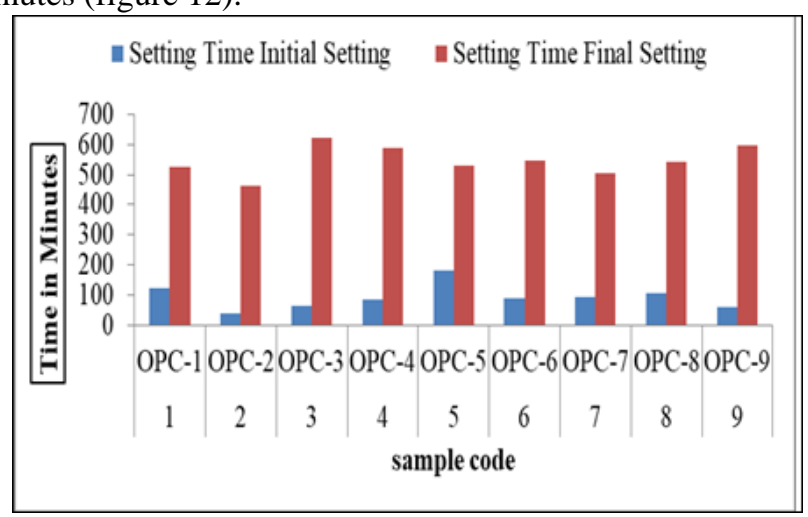

Figure 12 Results of Setting time Test

However, three cement types (OPC- 1,5and 8) significantly shows high initial setting time and one of them (OPC-3) is showing very high final setting time. Hence OPC-1,5and 8 should be used where transportation time required is more and use of OPC-3 should be avoided as it is having very high final setting time.

Compressive strength of mortar samples are tested on 3 days, 7 days, 28 days for 9 samples of ordinary Portland cement. According to IS compressive strength of mortar for 3 days should be more than 27MPa, for 7 days it should be more than $37 \mathrm{MPa}$, and standard compressive strength at 28 days should be more than 53MPa.All test samples comply with IS requirements, except sample code OPC- and thedifference in the strengths are shown in Figure 13.

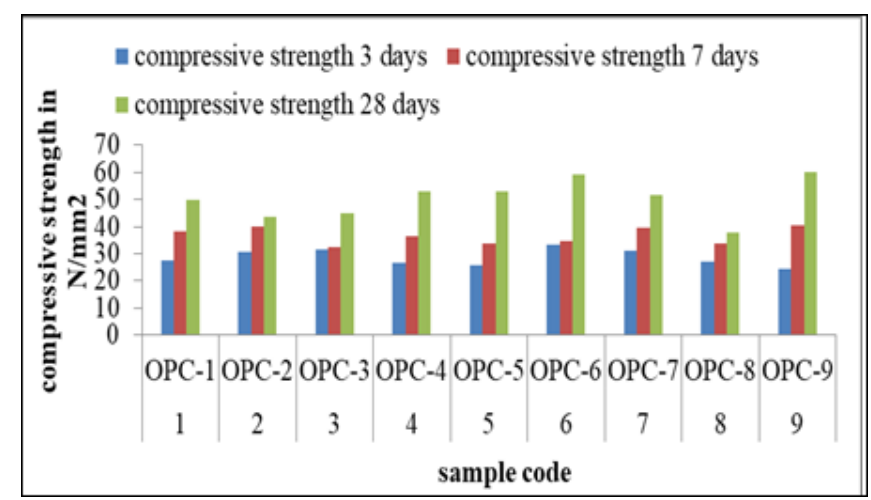

Figure 13: Results of Compressive strength test

Compressive strength is influenced by cement type, compound composition and fineness of cement. As the fineness of OPC-1 and 8 are high they are showing very less compressive strength.

The results obtained from the loss on ignition test are tabulated in Figure 14.

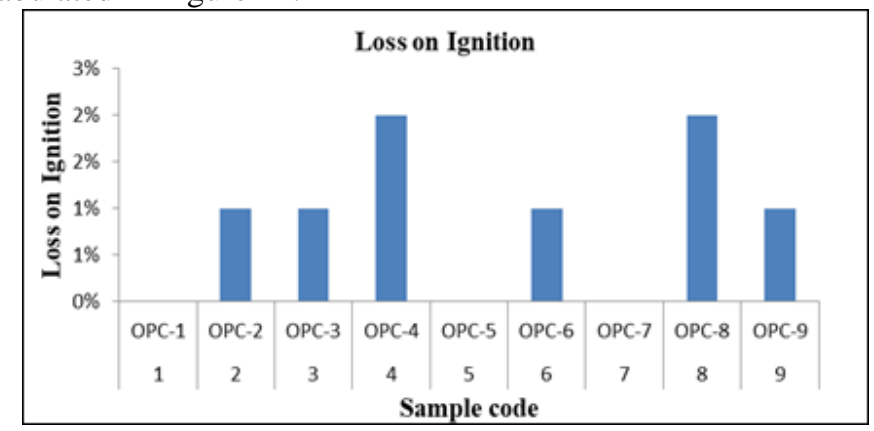

Figure 14: Results of LOI test

All the OPC samples are having the loss on ignition value within the BIS limit.

\section{PHYSICAL TESTS FOR PPC CEMENT}

According to BIS requirement, fineness should be less than or equal to $10 \%$.

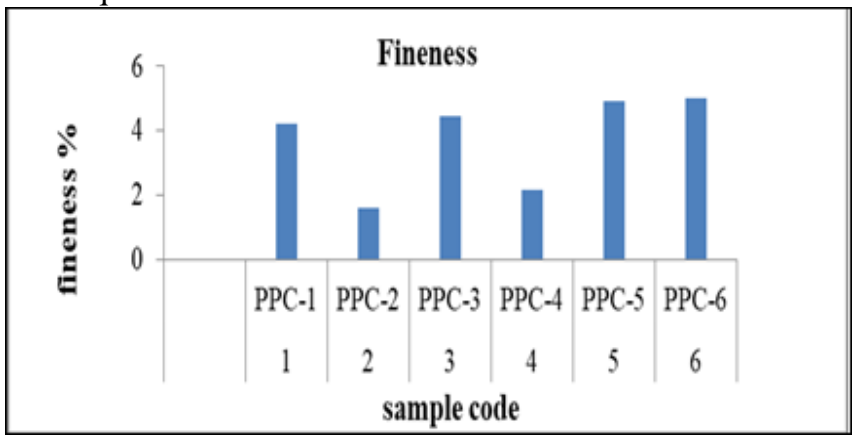

Figure 15: Results of Fineness Test

Fineness values vary from $1 \%$ to $5 \%$. All cement samples were showing the fineness results less than $10 \%$ (Figure 15). Hence could be used for construction of any structural element.

Standard consistency of cement paste are determined using the Vicat's Apparatus according to IS for all PPC cement samples and results of this test are shown in Figure 16. 


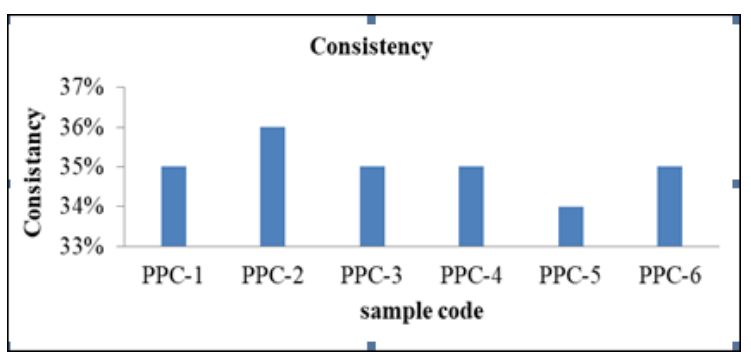

Figure 16: Results of Standard Consistency Test

Soundness test (Expansion) was done according to BIS using Le-Chateliermould. Results represented in Figure 17.

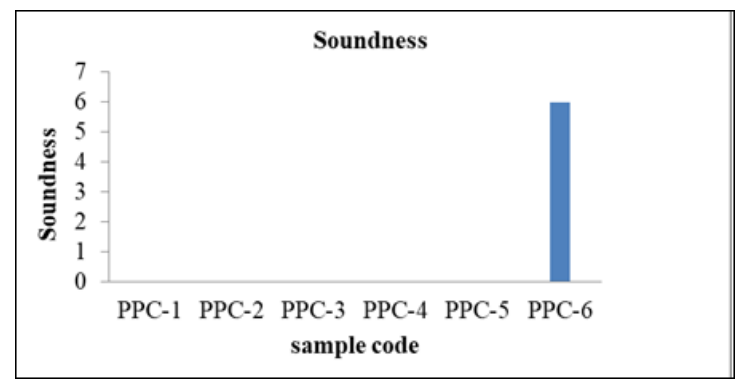

Figure 17: Results for Soundness test

All the results of soundness test are within the limits set by the BIS standards. The limiting value of soundness for Portland cements is $10 \mathrm{~mm}$.

Figure 18 shows the results of Initial and Final setting time test using vicat'smould. Initial setting time of most samples lies between 65 to 100 minutes and final setting lies between 730 to 850 minutes. This reveals that the rate of development of strength is slow in case of Portland Pozzolana Cement, as compared to Ordinary Portland Cement. This aspect should taken care while planning to use PPC for construction projects. Accordingly, stage of prestressing period of removal of form work and period of curing etc. should be suitably increased.

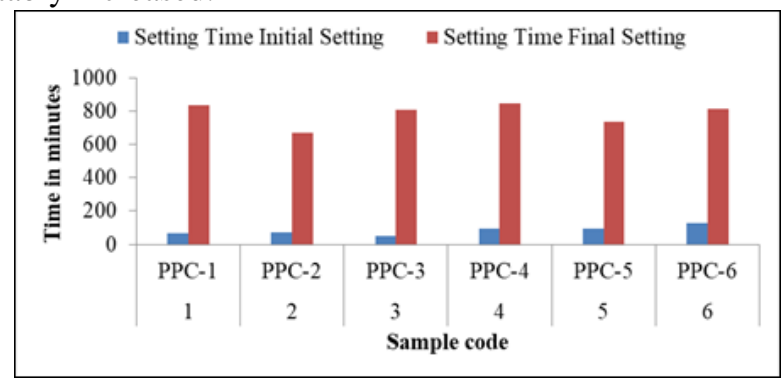

Figure 18: Results for Setting time test

Figure 19 shows the results obtained for compressive strength test.

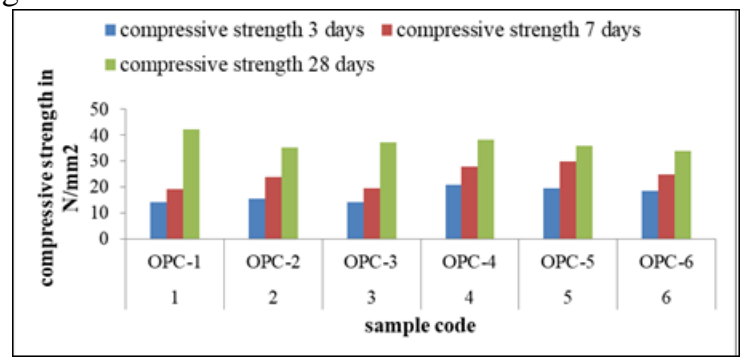

Figure 19: Results for Compressive strength test

Compressive strength is affected by cement type, compound composition and fineness of cement. As the fineness of PPC is more they are having very less compressive strength as compared to OPC.

Figure 20 indicates the results of loss on ignition test carried on PPC samples. As per BIS the limiting value for loss on ignition test is $5 \%$.

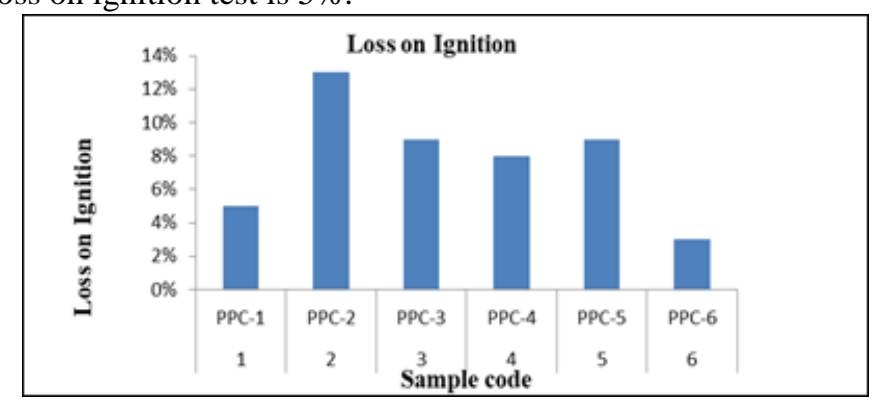

Figure 20: Results for LOI test

The sample code PPC- 2, 3, 4 and 5 are having quite high value of loss on ignition. A high loss on ignition can be attributed to properties such as pre-hydration and carbonation, which may be caused by improper and prolonged storage or adulteration during transport or transfer.

\section{CONCLUSIONS}

The physical properties (compressive strength, consistency, soundness, and fineness, initial and final setting time) and chemical composition of all the cement samples studied during this project are satisfying the BIS codal provisions. But few of these are showing very large variation with respect to BIS requirements. The following conclusions were made

Sample code OPC 1 and 8 are having very high fineness value resulting in low compressive strength. As lime content in the PPC is less therefore it gives low compressive strength as compared to OPC. Increased $\mathrm{Al}_{2} \mathrm{O}_{3}$ content of PPC results in higher value of initial and final setting time of cement. As the cement properties are not varying too much cement user can go for alternative for use of cement in civil engineering work and achieve economy in their projects.

\section{REFERENCES}

1. S. R. Neville, "Effect of Fineness on Portland Cement", Asian Journal of Civil Engineering Building and Housing, Vol. 11, No. 4, Pages 421-432, 1995.

2. Y. M. Zhang, and T. J. Napier, "The Effect of Particle Size Distribution \& Surface Area Upon Cement Strength Developement", Powder Technology, Vol. 83, Issue 3, Pages 245-252, 2000.

3. P. D. Tennis, and J. I. Bhatty, "Characteristics of Portland and Blended Cement", Concrete Technology Today, Vol 26, No. 3, Pages 1-3, 2005.

4. B Ceilk,. "The Effect of Particle Size Distribution \& Surface Area Upon Cement Strength Developement", Powder Technology, Vol.188, Issue 3, Pages 272-276. 2009 ,

5. Ige and O. Adekunle. "Comparative Analysis of Portland Cements In Nigeria", International Journal of Engineering Research \& Technology, Vol.2, Issue 3, Pages 387-392, 2013 
6. K. M. Lovely, "Strength Characteristics of Ordinary Portland Cement Due To Storage", International Journal of Modern Engineering Research, Vol. 4, Issue 8, Pages 154-160. 2013

7. T. Priyadarshana and R. Dissanayake, "Importance of Consistent Cement Quality For a Sustainable Construction", International Journal of Materials, Mechanics \& Manufacturing, Vol.1, No. 4, Pages 34-36,2013.

8. K. Amutha, and S. P., Vinayak, "Brand Preference of Selected Cements With Special Reference to Dindigul District", International Journal of Multidisciplinary Research And Development, Vol.200, Issue 2(1), Pages 263-267, 2014.

9. BIS: 4031. "Methods of Physical Tests For Hydraulic Cement" Part I to IV. Bureau of Indian Standards, New Delhi, 1988,

10. BIS: 4032. "Methods of chemical Tests For Hydraulic Cement". Bureau of Indian Standards, New Delhi, 1988,

11. M. L. Gambhir, "Concrete Technology- Theory and Practice”. McGrawHill Publication, New Delhi, fifth edition, 2017.

12. M. S. Shetty, "Concrete Technology- Theory and Practice", S Chand Publication, New Delhi, fifth edition, 2017 